\title{
TOBACCO, HEALTH AND INVESTOR-STATE DISPUTE SETTLEMENT: AUSTRALIA'S RECENT TREATY PRACTICE
}

\begin{abstract}
TANIA VOON*
[Australia has successfully defended its first investment treaty claim, brought by Philip Morris Asia Ltd under the bilateral investment treaty between Australia and Hong Kong. As researchers investigate the impact of such claims on treaty design, Australia provides an interesting case study. While causation between the Philip Morris claim and the drafting of Australia's newer international investment agreements cannot be established, some common threads appear in some of the agreements related to tobacco control and public health more broadly. Australia appears to be attempting in its various agreements to reach a balance between broad protections for public health that may prove difficult to interpret and apply and more concrete references to tobacco control (and other specified programs) that do not protect other aspects of health regulation.]
\end{abstract}

Keywords: Australia; dispute settlement; investment; international law; public health; tobacco

\begin{tabular}{|c|c|}
\hline \\
\hline \multicolumn{2}{|c|}{ I Introduction .. } \\
\hline II & Carveouts for Tobacco Control Measures \\
\hline III & Carveouts for Public Health Measures ..... \\
\hline IV & Other Protections for Public Health .... \\
\hline $\mathrm{V}$ & 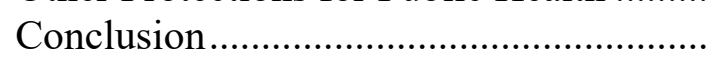 \\
\hline
\end{tabular}

\footnotetext{
* Professor, Melbourne Law School, University of Melbourne; PhD (Cantab); LLM (Harv); Dip Intl Law, LLB (Hons), BSc (Melb); AMusA. Email: <tania.voon@unimelb.edu.au>. Parts of this article arise from independent research funded by the Australian Research Council pursuant to the Linkage Project scheme (Project ID LP120200028). I have previously advised government departments and NGOs on tobacco plain packaging and related issues. This article contains my views as an academic and does not necessarily reflect those of any employer or other entity. Any errors or omissions are mine.
} 


\section{INTRODUCTION}

The claim brought by Philip Morris Asia Ltd against Australia's tobacco plain packaging scheme under Australia's bilateral investment treaty ('BIT') with Hong Kong ${ }^{1}$ was this country's first experience as respondent in an investment treaty arbitration. Since then, Australia has faced two more claims, ${ }^{2}$ although they do not appear to be proceeding very far or very quickly ${ }^{3}$ (unsurprisingly, since they are brought pursuant to an international investment agreement ('IIA') 4 that contains no mechanism for investor-state dispute settlement ('ISDS')). Recent empirical research indicates that subjecting a host state to an investment treaty claim increases the chance of it renegotiating its IIAs to provide greater policy space or to terminate IIAs. ${ }^{5}$ Renegotiation and termination provide important means of reforming the international investment regime. Exposure to ISDS claims might also be expected to affect the content of new IIAs negotiated by such states.

In Australia's case, it is not possible as an academic outsider to link the timing of or motivations for changes in treaty practice to the Philip Morris dispute. Nevertheless, ongoing developments in and beyond Australia in investment treaty design mean that a future such dispute brought under a more modern IIA might be resolved somewhat differently. The Philip Morris claim was denied on jurisdictional grounds, ${ }^{6}$ albeit after significant time and resources had been spent, including on merits arguments. ${ }^{7}$ One reason for introducing changes to ISDS provisions in IIAs today is to try to minimise the costs of defending a claim, not only by ensuring that non-meritorious claims fail, but also by bringing to an early resolution certain types of claims.

1 Agreement between the Government of Australia and the Government of Hong Kong for the Promotion and Protection of Investments, signed 15 September 1993, [1993] ATS 30 (entered into force 15 October 1993) ('Australia-Hong Kong BIT').

2 See Jarrod Hepburn, 'US Investors Mired in Australian Dispute Contend That State-to-State Consultations, If Launched, Must Be Followed by Investor-State Arbitration', Investment Arbitration Reporter (online, 1 December 2015) <https://www.iareporter.com/articles/us-investors-mired-in-australian-dispute-contend-that-state-to-stateconsultations-if-launched-must-be-followed-by-investor-state-arbitration/ $>$, archived at $<$ https://perma.cc/GG7XNE4R>; Jarrod Hepburn, 'A Second US Investor Tries to Arbitrate under Australia-US FTA, despite Absence of an Investor-State Arbitration Mechanism', Investment Arbitration Reporter (online, 24 April 2017) $<$ https://www.iareporter.com/articles/a-second-us-investor-tries-to-arbitrate-under-australia-us-fta-despite-absenceof-an-investor-state-arbitration-mechanism/>, archived at $<$ https://perma.cc/TX28-MQ4M>.

${ }^{3}$ See Christopher Knaus, 'US Company's Attempt to Sue Australian Government Collapses', The Guardian (online, 20 April 2019) <https:/www.theguardian.com/australia-news/2019/apr/20/us-companys-attempt-to-sue-australiangovernment-collapses $>$, archived at $<$ https://perma.cc/BT7A-5JD5>.

${ }^{4}$ Australia-United States Free Trade Agreement, signed 18 May 2004, [2005] ATS 1 (entered into force 1 January 2005).

${ }^{5}$ Alexander Thompson, Tomer Broude and Yoram Z Haftel, 'Once Bitten, Twice Shy? Investment Disputes, State Sovereignty and Change in Treaty Design' (forthcoming, International Organization) $<$ https://ssrn.com/abstract=3367800 $>28$.

${ }^{6}$ Philip Morris Asia Ltd v Australia, PCA Case No 2012-12, Award on Jurisdiction and Admissibility (17 December 2015). See also Tania Voon and Andrew D Mitchell, 'Philip Morris vs Tobacco Control: Two Wins for Public Health but Uncertainty Remains', Columbia FDI Perspectives (online, No 182, 12 September 2016).

${ }^{7}$ Philip Morris Asia Ltd v Australia, PCA Case No 2012-12, Procedural Order No 4 (26 October 2012) [68]: '[T]he Tribunal concludes that the decision regarding bifurcation should be postponed until after a full Statement of Claim and a full Statement of Defence on all aspects of the case are submitted'. 
In Part II of this short article, I examine several IIA provisions that 'carve out' tobacco control from the operation of ISDS mechanisms, disallowing ISDS claims against tobacco control measures to some extent, as well as certain other specified programs. These kinds of carveouts evidently protect tobacco control measures but offer no protection for regulatory sovereignty with respect to other areas of public health. In Part III, I identify certain other carveouts that address this problem by excluding from ISDS 'public health' measures, nevertheless creating more scope for argument about which measures are covered.

Part IV addresses two other possibilities for protecting public health regulation from ISDS claims, namely abandoning ISDS (which is not consistent with the current Australian government's ad hoc approach to including ISDS in its IIAs) and introducing a procedural mechanism whereby the states party to the treaty may agree that a challenged measure is excluded from ISDS scrutiny because it is a 'public welfare' measure. This latter approach seems to strike the best balance between overly broad provisions (which may leave too much uncertainty and scope for extended proceedings) and overly narrow provisions (which may help cut short proceedings but without providing sufficient protection to the wide range of legitimate health measures that might be challenged).

\section{CARVEOUTS FOR TOBACCO CONTROL MEASURES}

The first 'carveout' from ISDS for tobacco control measures arose in the original Trans-Pacific Partnership Agreement ('TPP'), ${ }^{8}$ which specified in its 'Exceptions and General Provisions' chapter that a TPP party could 'elect to deny the benefits of Section B of Chapter 9' (allowing ISDS claims) 'with respect to claims challenging a tobacco control measure of the Party', in which case no such claim could be submitted to arbitration. ${ }^{9}$ An election could be made under this provision in general (before the submission of a claim) or later (when proceedings have already commenced, in which case the relevant claim would be dismissed). ${ }^{10}$ Some countries including Australia promptly gave notice of their election to deny benefits to tobacco control claims in this way. $^{11}$

The TPP provision made clear that state-state dispute settlement was still available with respect to tobacco control measures: the potential for a host state to elect to deny dispute settlement benefits applied only to ISDS. ${ }^{12}$ The provision also contained a detailed definition of 'tobacco control measure' meaning a 'measure of a Party related to the production or consumption of manufactured tobacco products ... their distribution, labelling, packaging, advertising, marketing, promotion,

\footnotetext{
${ }^{8}$ Trans-Pacific Partnership Agreement, signed 4 February 2016, [2016] ATNIF 2 (not in force) ('TPP').

${ }^{9} \mathrm{TPP}$ art 29.5 .

${ }^{10} \mathrm{TPP}$ art 29.5 .

${ }^{11}$ See, eg, Notification by Australia pursuant to Article 29.5 of the Trans-Pacific Partnership Agreement (15 February 2016); National Interest Analysis (Australia) [2016] ATNIA 4 (4 February 2016) [5]; Trans-Pacific Partnership National Interest Analysis (New Zealand) (25 January 2016) 252.

${ }^{12} T P P \operatorname{ch} 29$ n 11.
} 
sale, purchase, or use, as well as enforcement measures'. ${ }^{13}$ Measures with respect to 'tobacco leaf' not in possession of a tobacco product manufacturer or part of a manufactured tobacco product fell outside the definition. ${ }^{14}$

This provision was retained when the TPP was incorporated into the Comprehensive and Progressive Agreement for Trans-Pacific Partnership ('CPTPP'). ${ }^{15} \mathrm{On}$ one view, this carveout is a success for tobacco control objectives and should be replicated in other agreements, even if it is limited by the need for host state election and the restriction of tobacco control measures to manufactured tobacco products. ${ }^{16}$ Allowing a claim against a tobacco control measure to be dismissed by virtue of this specific provision is also likely to address concerns about costly and time-consuming proceedings as in the Australian case brought by Philip Morris. However, the targeted nature of the provision means that it does nothing to address broader public health or public policy objectives or general concerns about the legitimacy of the investment treaty regime. ${ }^{17}$ The inclusion of such a carveout also raises questions about the potential impact on treaties lacking a carveout. $^{18}$

The TPP-based carveout has been replicated in two further Australian IIAs, albeit without the requirement for host state election. The omission of this requirement make sense outside the context of the TPP/CPTPP since the newer IIAs are between just two parties. The carveout in these IIAs therefore provides more certain protection to tobacco control measures from ISDS claims. Amendments to the Singapore-Australia Free Trade Agreement signed in October 2016 added a simple clause to the investment chapter's section B (ISDS) specifying that 'No claim may be brought under this Section in respect of a tobacco control measure of a Party'. ${ }^{19}$ The SAFTA definition of tobacco control measure is slightly modified but still appears restricted to measures relating to products that are 'manufactured to be used for smoking, sucking, chewing or snuffing'. ${ }^{20}$ The SAFTA amendments also prevented ISDS claims against certain Australian measures, namely those comprising or related to the Pharmaceutical Benefits Scheme, Medicare

\footnotetext{
${ }^{13} T P P \operatorname{ch} 29$ n 12.

${ }^{14} T P P \operatorname{ch} 29$ n 12.

15 Comprehensive and Progressive Agreement for Trans-Pacific Partnership, signed 8 March 2018, [2018] ATS 23 (entered into force for Australia, Canada, Japan, Mexico, New Zealand and Singapore on 30 December 2018 and for Vietnam on 14 January 2019) ('CPTPP') art 1.1.

${ }^{16}$ See, eg, Katherine Hirono, Deborah Gleeson and Becky Freeman, 'To What Extent Does a Tobacco Carve-Out Protect Public Health in the Trans-Pacific Partnership Agreement?' (2016) 26(2) Public Health Research \& Practice e2621622.

${ }^{17}$ See Andrew D Mitchell, Elizabeth Sheargold and Tania Voon, Regulatory Autonomy in International Economic Law: The Evolution of Australian Policy on Trade and Investment (Edward Elgar Publishing, 2017) 192; Andrew D Mitchell, Tania Voon and Devon Whittle, 'Public Health and the Trans-Pacific Partnership Agreement' (2015) 5(2) Asian Journal of International Law 279, 291-293.

${ }^{18}$ But see Andrew D Mitchell and James Munro, 'Someone Else's Deal: Interpreting International Investment Agreements in the Light of Third-Party Agreements' (2017) 28(3) European Journal of International Law 669.

19 Singapore-Australia Free Trade Agreement, signed 17 February 2003, [2003] ATS 16 (entered into force 28 July 2003), as amended from 24 February 2006, 13 February 2007, 11 October 2007, 2 September 2011 and 1 December 2017 ('SAFTA') ch 8 art 22.

${ }^{20}$ SAFTA ch 8 n 19 (emphasis added).
} 
Benefits Scheme, Therapeutic Goods Administration and Office of the Gene Technology Regulator. ${ }^{21}$

The SAFTA carveout has been followed in the new IIA signed by Australia and Hong Kong on 26 March 2019. This agreement will replace ${ }^{22}$ the existing old-style BIT between Australia and Hong Kong. ${ }^{23}$ The carveout is contained in a footnote that combines the exclusion with the definition of 'control measures of tobacco products'. ${ }^{24}$ This IIA also excludes ISDS claims against the same Australian measures as the amended SAFTA. A difficulty with such piecemeal exclusions, as with the tobacco control carveout, is they do not provide protection for analogous programs (except successor programs, which are explicitly mentioned in both the SAFTA and the new IIA with Hong Kong), including those that may be developed in future to address new technologies or risks. ${ }^{25}$

These developments with respect to tobacco control measures in the TPP/CPTPP and Australian IIAs have the potential to be duplicated elsewhere, including by spreading through $C P T P P$ and IIA partners. The CPTPP tobacco control carveout will have greater significance for Australia as well because Australia's BITs with Mexico, Peru and Vietnam are being terminated upon entry into force of the CPTPP for the relevant parties. Given Australia's election as a host state to deny the benefits of ISDS to tobacco control under the $C P T P P$, the termination of these earlier treaties will remove existing avenues for ISDS against tobacco control measures (subject to the relevant survival clauses as agreed by the parties).

A recent BIT concluded between Singapore and Kazakhstan states that the ISDS mechanism 'shall not apply to any dispute concerning any measure adopted or maintained or any treatment accorded to investors or investments by a Party in respect of tobacco or tobacco-related products' ${ }^{26}$ The definition of tobacco or tobacco-related products extends beyond tobacco products and does not appear explicitly linked to manufactured products. The carveout also does not refer to tobacco 'control' measures, meaning that this carveout has a potentially wider scope of application while still centred on tobacco.

A continuing expansion and proliferation of tobacco measure carveouts from ISDS may not be ideal from the perspective of maintaining public health in general. Instead, broader references to public health as discussed further below may better protect states' health objectives. Nevertheless, the broader the reference the more scope there may be for debate about whether a measure falls within it. A tobacco control carveout, at least with respect to obvious tobacco control measures, is

\footnotetext{
${ }^{21}$ SAFTA ch 8 n 18.

22 Investment Agreement between the Government of Australia and the Government of the Hong Kong Special Administrative Region of the People's Republic of China (signed 26 March 2019, not yet in force) ('Australia-Hong Kong IIA') art 40.2.

${ }^{23}$ Australia-Hong Kong BIT (n 1).

${ }^{24}$ Australia-Hong Kong IIA (n 22) n 14.

25 See Mitchell et al (n 17) 194.

${ }^{26}$ Agreement between the Government of the Republic of Kazakhstan and the Government of the Republic of Singapore on the Promotion and Mutual Protection of Investments, signed 21 November 2018 (not yet in force) art 11.2.
} 
likely to have the benefit of cutting short proceedings and associated costs without the need for arguments on the merits of a claim.

\section{Carveouts for Public Health Measures}

Two recent Australian IIAs take a broader approach than the tobacco control carveouts, but consistent with the idea that some policy objectives are best excluded from ISDS claims. Specifically, these treaties exclude public health measures from such claims. The Peru-Australia Free Trade Agreement ('PAFTA') ${ }^{27}$ states in a footnote to Section B (ISDS) of the Investment Chapter:

No claim may be brought under this Section in relation to a measure that is designed and implemented to protect or promote public health. For greater certainty, for Australia, such measures include: measures comprising or related to the Pharmaceutical Benefits Scheme, Medicare Benefits Scheme, Therapeutic Goods Administration and Office of the Gene Technology Regulator. A reference to a body or program in this footnote includes any successor of that body or program. ${ }^{28}$

By including a non-exhaustive list of measures that are designed and implemented to protect or promote public health, this provision is not limited to the programs explicitly mentioned such as the Pharmaceutical Benefits Scheme. The exclusion therefore has the potential to cover future programs that are not yet developed, even though the broader nature of the provision entails more scope for argument about whether such programs are in fact designed and implemented to protect or promote public health. By explicitly listing certain specified programs, Australia has the benefit of certainty that these programs at least are covered.

The Indonesia-Australia Comprehensive Economic Partnership Agreement ('IA-CEPA') ${ }^{29}$ similarly provides that no claim may be brought under Section B of (ISDS) of its Investment Chapter 'in relation to a measure that is designed and implemented to protect or promote public health', ${ }^{30}$ which is again stated to include 'measures that comprise or relate to the Pharmaceutical Benefits Scheme, Medicare Benefits Scheme, Therapeutic Goods Administration, and Office of the Gene Technology Regulator'. ${ }^{31}$ Strangely, no reference is made to successor programs of those listed, although these would arguably be covered anyway as unlisted measures designed and implemented to protect or promote public health.

\footnotetext{
${ }^{27}$ Free Trade Agreement between Australia and the Republic of Peru, signed 12 February 2018, [2018] ATNIF 5 (not yet in force) ('PAFTA').

${ }^{28}$ PAFTA ch 8 s B n 17 (emphasis added).

${ }^{29}$ Indonesia-Australia Comprehensive Economic Partnership Agreement, signed 4 March 2019, [2019] ATNIF 17 (not yet in force) (' $I A-C E P A$ ').

${ }^{30} I A-C E P A$ art $14.21 .1(\mathrm{~b})$.

${ }^{31} I A-C E P A$ ch 14 n 21(1).
} 


\section{Other Protections For Public HeAlth}

Various other protections for public health exist in modern IIAs, such as references to public health or public health programs or measures in a state's list of non-conforming measures with respect to particular investment obligations, or general exceptions ${ }^{32}$ for public health. However, some additional protections for public health also arise specifically with respect to ISDS. The significance of such protections, as noted above, is their potential to stop a claim earlier even if the claim would not have succeeded on the merits in due course, thereby saving time and costs.

Excluding ISDS altogether is of course one option to avoid the costs of an ISDS claim against a public health measure. For example, the Pacific Agreement on Closer Economic Relations Plus ('PACER Plus' $)^{33}$ signed among Australia, New Zealand and nine Pacific Island countries contains an investment chapter but no ISDS. ${ }^{34}$ Instead, the agreement provides for state-state dispute settlement. While excluding the costs of ISDS, this approach also excludes any potential benefits of ISDS, such as protecting and promoting inward and outward investment. Nevertheless, the evidence of such benefits, and of the economic impact of IIAs more generally, is currently inconclusive. ${ }^{35}$

A more nuanced approach that provides greater scope for ISDS to offer benefits to states and investors is found in the China-Australia Free Trade Agreement ('ChAFTA'). ${ }^{36}$ It contains an exclusion for public welfare measures as well as a procedural mechanism for giving effect to the exclusion. Article 9.11.4 states:

Measures of a Party that are non-discriminatory and for the legitimate public welfare objectives of public health, safety, the environment, public morals or public order shall not be the subject of a claim under this Section [ISDS]. ${ }^{37}$

This exclusion goes beyond public health to other policy objectives over which the states party and investor claimant might disagree. However, such disagreement would be resolved by the states party to the treaty. Under Article 9.11.5, a respondent host state who considers that an ISDS claim is being made against a public welfare measure may provide a 'public welfare notice' to the

\footnotetext{
${ }^{32}$ See generally Andrew D Mitchell, James Munro and Tania Voon, 'Importing WTO General Exceptions into International Investment Agreements: Proportionality, Myths and Risks' in Lisa Sachs, Lise Johnson and Jesse Coleman (eds), Yearbook on International Investment Law \& Policy 2017 (Oxford University Press, 2019) 305.

${ }^{33}$ Pacific Agreement on Closer Economic Relations Plus, signed 14 June 2017, [2017] ATNIF 42 (not yet in force) ('PACER Plus').

${ }^{34}$ Ibid ch 9 .

${ }^{35}$ See, eg, Jonathan Bonnitcha, Lauge N Skovgaard Poulsen and Michael Waibel, The Political Economy of the Investment Treaty Regime (Oxford University Press, 2017) 57; Jonathan Bonnitcha and Emma Aisbett, 'An Economic Analysis of the Substantive Protections Provided by Investment Treaties' in Karl P Sauvant (ed), Yearbook on International Investment Law \& Policy 2011-2012 (Oxford University Press, 2013) 681; Taylor St John, The Rise of Investor-State Arbitration: Politics, Law, and Unintended Consequences (Oxford University Press, 2018) 249 (on the multiple purposes ascribed to ISDS).

${ }^{36}$ Free Trade Agreement between the Government of Australia and the Government of the People's Republic of China, signed 17 June 2015, [2015] ATS 15 (entered into force 20 December 2015) ('ChAFTA').

${ }^{37}$ ChAFTA art 9.11.4.
} 
investor claimant and the non-disputing home state, 'specifying the basis for its position'. ${ }^{38}$ A 90day period of consultations between the home and host states will then take place. ${ }^{39} \mathrm{~A}$ decision by those states that a measure is in fact a public welfare measure of the kind described in Article 9.11.4 is binding on the arbitral tribunal, which must ensure that any award issues is consistent with the decision. ${ }^{40}$

This approach to the procedure surrounding public welfare measures gives the states control over the scope of the exclusion, to the extent that they are able to agree. In other words, they have the opportunity to reach their own agreement rather than leaving this controversial question to be resolved by the investment treaty tribunal. The procedure also provides the opportunity to reduce the costs of proceedings because of the states are able to reach agreement the tribunal will not need to examine whether the measure falls within Article 9.11.4 or not.

\section{CONCLUSION}

As an academic outsider, it is difficult to draw conclusions from the wording of Australia's recent IIAs about the country's preferences and positions with respect to tobacco control and public health, because these treaties are drafted with different partners with their own preferences. Clearly Australia has concerns about ISDS affecting public health programs, particularly in connection with the Pharmaceutical Benefits Scheme, Medicare Benefits Scheme, Therapeutic Goods Administration and Office of the Gene Technology Regulator. Beyond those specific programs, the variation in the agreements leaves unclear Australia's intentions with respect to the coverage of public health by ISDS mechanisms. But the current government's position is that ISDS is to be pursued on an ad hoc basis, meaning that ISDS is not to be eschewed altogether, even though that is the current status under PACER Plus.

The CPTPP's carveout from ISDS of tobacco control measures at the election of the host state may seem linked to the investment treaty claim brought against Australia by Philip Morris Asia Ltd, but the carveout may have been pushed equally or more by other treaty partners including the United States. Similarly, the tobacco control carveout in Australia's IIAs with Singapore and Hong Kong may have arisen from those countries' demands rather than Australia's. Recognising the difficulties associated with overly specific provisions that do little to protect broader public health objectives, perhaps Australia's true preferences are better reflected in the IIAs with Peru and Indonesia, which preclude ISDS claims against public health measures. That broader approach nevertheless leads to other difficulties, such as uncertainty about the scope of the exclusion and the potential for tribunals to opine on the meaning of public health in unintended ways.

The use of a procedural mechanism in ChAFTA to give the states party to the treaty power over the meaning of a 'public welfare' measure represents a novel hybrid between overly specific

\footnotetext{
${ }^{38}$ ChAFTA art 9.11.5.

${ }^{39}$ ChAFTA art 9.11.6.

${ }^{40}$ ChAFTA art 9.18.3.
} 
exclusions (eg covering only tobacco control measures or the Pharmaceutical Benefits Scheme) and overly broad exclusions left in the hands of arbitrators (eg 'public health' or 'public welfare'). Although the parties might not be able to reach agreement on whether a given measure falls within the meaning of the public welfare provision, this opportunity reduces some of the concerns about tribunals' expansive powers and also has the potential to reduce financial costs and time taken in arbitral proceedings. In one sense, this approach brings ISDS a degree closer to state-state dispute settlement. In my view it is the preferred approach of those presented.

On 5 April 2019, Australia signed a new BIT with Uruguay, which will replace the existing BIT between the two countries ${ }^{41}$ upon its entry into force. ${ }^{42}$ Like Australia, Uruguay successfully defended an investment treaty claim brought by a Philip Morris entity in recent years. ${ }^{43}$ Yet the new BIT does not contain a tobacco control carveout from ISDS, or a broader carveout from ISDS for public health measures. Instead, the BIT relies on more substantive protections such as general exceptions extending to measures 'necessary to protect human, animal or plant life or health', ${ }^{44}$ and a common clarification that "non-discriminatory regulatory actions by a Party that are designed and applied to protect legitimate public welfare objectives, such as public health, safety and the environment, do not constitute indirect expropriations ${ }^{45}$ (along with a detailed footnote containing an inclusive list of such measures). ${ }^{46}$

This kind of drafting exemplifies the trade-offs involved in trying to protect matters of public health, by two countries who are both evidently committed to tobacco control. These provisions provide strong indications of the parties' intentions with respect to public health and would certainly assist in defending public health measures, although they may do little to bring an early end to proceedings in the way that some of the more ISDS-targeted carveouts might do. Instead, the host state would have to wait for the tribunal to rule on these provisions or hope that they are sufficient to deter a claim contrary to health objectives.

\footnotetext{
41 Agreement between Australia and Uruguay on the Promotion and Protection of Investments, signed 3 September 2001 (entered into force 12 December 2002).

42 Agreement between Australia and the Oriental Republic of Uruguay on the Promotion and Protection of Investments, signed 5 April 2019 (not yet in force) art 17.5 ('Australia-Uruguay BIT 2019').

${ }^{43}$ Philip Morris Brands Sàrl et al v Uruguay, ICSID Case No ARB/10/7, Award (8 July 2016).

${ }^{44}$ Australia-Uruguay BIT 2019 art 15.1(a).

${ }^{45}$ Australia-Uruguay BIT 2019 annex B [3(b)].

${ }^{46}$ Australia-Uruguay BIT 2019 annex B n 4.
} 


\section{University Library}

\section{- M M I N E R VA A gateway to Melbourne's research publications}

Minerva Access is the Institutional Repository of The University of Melbourne

Author/s:

Voon, $\mathrm{T}$

Title:

Tobacco, Health and Investor-State Dispute Settlement: Australia's Recent Treaty Practice

Date:

2020

Citation:

Voon, T. (2020). Tobacco, Health and Investor-State Dispute Settlement: Australia's Recent Treaty Practice. Australian Year Book of International Law, 37 (1), pp.89-98

Persistent Link:

http://hdl.handle.net/11343/243788 